\title{
Association of Cytomegalovirus (CMV) Infection with Guillain- Barré Syndrome (GBS) In Tertiary Care Hospital (BSMMU) of Bangladesh
}

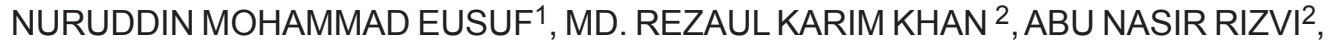 \\ SHEIKHABDUL KADER ${ }^{3}$, ABU JAFOR MD. SALAHUDDIN ${ }^{4}$, RASHED IMAM ZAHID ${ }^{1}$, \\ KHAIRUL KABIR PATWARY ${ }^{5}$, MOHAMMAD SAYEED HASAN ${ }^{6}$, MD. KABIRUZZAMAN ${ }^{5}$, \\ MD. ABDUL ALIM ${ }^{5}$, SAMSUN NAHAR ${ }^{7}$, MASUD RANA $^{8}$
}

\begin{abstract}
:
Background: Guillain-Barré syndrome (GBS) usually preceded by infections, in particular cytomegalovirus (CMV). It may occur by primary infection, reinfection or by reactivation of CMV. Objective: The aim of the present study was to evaluate the association of Guillain-Barré syndrome (GBS) with Cytomegalovirus (CMV) infection. Methodology: This case control study was carried out in the indoor and outpatient Department of Neurology at Bangabandhu Sheikh Mujib Medical University (BSMMU), Dhaka from $1^{\text {st }}$ January 2010 to $31^{\text {st }}$ December 2011 for the duration of two years. All patients with GBS, who attended in neurology OPD or inpatient department at BSMMU during the study period, fulfilling the inclusion and exclusion criterias were included in this study. Age \& sex matched volunteers, patients attendants, patients other than GBS who were nondiabetic, had no renal or hepatic diseases or family history of polyneuropathy were included in control group. Results: A total number of 78 respondents of which 39 patients were taken as cases and rest 39 were taken as controls who appeared in neurology OPD or inpatient department at BSMMU during the study period, fulfilling the inclusion and exclusion criterias were included in this study. The mean age $\pm S D$ of case and control groups were $30.82 \pm 12.56$ and $31.00 \pm 12.77$ years respectively $(p=0.950)$. In case group the history of respiratory tract infection was present in $46.2 \%$ cases and absent in control group ( $p=0.001)$. In case group the history of gastroenteritis was present in $28.2 \%$ cases and absent in control group $(p=0.001)$. In case group the history of fever was present in $30.8 \%$ cases and absent in control group ( $p=0.001)$. Anti-CMV IgM antibody was positive in $5.1 \%$ cases. Four fold rise of IgG in case group was present in $10.3 \%$ cases and absent in control group $(p=0.040)$. Confirmed CMV infected GBS cases were $15.4 \%$ and absent in control group ( $p=0.011)$. Conclusion: The findings of this study permit to conclude that there is a significant association of Guillain-Barré syndrome (GBS) with Cytomegalovirus (CMV) infection.
\end{abstract}

Keywords: Cytomegalovirus (CMV), Guillain-Barré Syndrome (GBS).

\section{Introduction:}

Guillain-Barré syndrome (GBS) now ranks as the most frequent cause of acute flaccid paralysis since the near-elimination of poliomyelitis throughout the world and its median annual incidence is 1 to 2 per 100,000 populations ${ }^{1}$. According to an epidemiologic survey, the average annual incidence of GBS in the United States is

1. Indoor Medical Offocer, National Institute of Neurosciences and Hospital, Dhaka.

2. Professor, Department of Neurology, Bangabandhu Sheikh Mujib Medical University, Dhaka.

3. Associate Professor, Department of Neurology, Bangabandhu Sheikh Mujib Medical University, Dhaka.

4. Registrar, Peadiatric Neurology, National Institute of Neurosciences and Hospital, Dhaka.

5. Medical Officer, Deptt of Neurology, National Institute of Neurosciences and Hospital, Dhaka

6. Junior Consultant, National Institute of Neurosciences and Hospital, Dhaka

7. Professor, Department of Physical Medicine \& Rehabilitation, Bangabandhu Sheikh Mujib Medical University, Dhaka.

8. Medical Officer, Department of Neurology, Bangabandhu Sheikh Mujib Medical University, Dhaka. 
3.0 cases per 100,000 populations. With poliomyelitis under control in developed countries, GBS is the most important cause of acute flaccid paralysis.

GBS remains a diagnosis made primarily through the assessment of clinical history and findings ${ }^{2}$.

In epidemiologic surveys, the overall death rate related to GBS ranges from $2-12 \%$ of patients. Deaths usually occur in ventilator-dependent patients, resulting from such complications as pneumonia, sepsis, adult respiratory distress syndrome, and less frequently, autonomic dysfunction ${ }^{3}$. Although the classic description of GBS is that of a demyelinating neuropathy with ascending weakness, many clinical variants have been well documented in the medical literature.

GBS is a post-infectious, immune-mediated disease. Cellular and humoral immune mechanisms probably play a role in its development. Most patients report an infectious illness in the weeks prior to the onset of GBS. Many of the identified infectious agents are thought to induce antibody production against specific gangliosides and glycolipids, such as $\mathrm{GM}_{1}$, $\mathrm{GM}_{2}$ and $\mathrm{GD}_{1}$ a etc, distributed throughout the myelin in the peripheral nervous system ${ }^{4}$. The favored hypothesis is that the immune response to certain infective agents in some people may trigger cross reactive immunity, with initially one or more myelin or axonal antigens leading to an autoimmune attack on the nerve tissue. Antiglycolipid antibodies have often been found in affected patients ${ }^{5}$.

The pathophysiologic mechanism of an antecedent illness and of GBS can be typified by Campylobacter jejuni infections ${ }^{6}$.

A preceding CMV infection with high titres of IgM antibody has been implicated in $10-15 \%$ of the patients with $\mathrm{GBS}^{7}$.

Cytomegalovirus is a member of â herpes virus group. It is a DNA virus having double stranded DNA. It causes primary infection, reactivation or reinfection. Route of transmission are by breast milk, saliva, sexual transmission, blood transmission, organ transplantation and droplet infection etc ${ }^{8}$.

In primary infection IgM against CMV develop and persist for 3-4 months, but in case of reinfection or reactivation IgM is not usually found, IgG is found. $\lg$ is persist for life long ${ }^{7}$. It has also suggested raised concentrations of antibodies to ganglioside GM2 in patients with GBS after cytomegalo virus (CMV) infection ${ }^{9}$. The association between antiganglioside antibody responses and Guillan-Barré syndrome (GBS) after a recent cytomegalovirus (CMV) infection Khalili SA et al. ${ }^{10}$, conducted a study. They concluded that antibodies to ganglioside GM2 are often associated with GBS after CMV infection, but their relevance is not known. It is unlikely that CMV infection and anti-ganglioside GM2 antibodies are solely responsible and an additional factor is required to elicit $\mathrm{GBS}^{10}$.

Guillain-Barré syndrome may occur by primary infection or by reinfection or reactivation of $\mathrm{CMV}^{11}$. To study the association of cytomegalo virus infection with Guillian-Barre syndrome needs diagnosis of CMV infection which required at least one of the following laboratory method:- serology, specific intrathecal antibody production, virus isolation, direct detection of CMV PP65 antigen in blood, CMV culture, biopsy, positive specific immunohistochemical staining, polymerase chain reaction $(\mathrm{PCR})$ assay etc ${ }^{8}$.

Serological studies indicating an acute CMV infection includes:

1. The presence of positive IgM anti CMV antibodies with undectable CMV specific lgG antibodies, or

2. Presence of CMV specific IgG antibodies of low avidity in the presence or absence of virus specific lgM antibodies ${ }^{11}$.

3. Presence of increase in the titre of IgG anti CMV antibodies in paired sample obtained during the infection ${ }^{8}$.

This study was evaluated by serological test. The proposed study was evaluated the relationship of CMV infection with GBS. This study was focused on new insights into the epidemiology and information concerning the relationship between CMV infection and GBS.

\section{Methods:}

This is a case-control study. The study was carried out in the Department of Neurology, Bangabandhu Sheikh Mujib Medical University (BSMMU), Dhaka. This study was conducted from $1^{\text {st }}$ January 2010 to 
$31^{\text {st }}$ December 2011 for the duration of two years. All patients with GBS, who attended in neurology department, BSMMU during the study period, fulfilling the inclusion and exclusion criteria were included in this study. Age \& sex matched volunteers, patient's attendants who were non-diabetic, had no renal or hepatic diseases or family history polyneuropathy were included in control group. A total number of 78 study subject, 39 patients presented with GuillainBarre syndrome and 39 controls were enrolled in this study by purposive sampling.

All data were compiled and edited meticulously by thorough checking and rechecking. All omissions and inconsistencies were corrected and were removed methodically.

All data were recorded systematically in preformed data collection form (questionnaire) and quantitative data was expressed as mean and standard deviation, and qualitative data was expressed as frequency distribution and percentage. Statistical analysis was performed by using Statistical Package for Social Science (SPSS) for windows version 12.0. 95\% confidence limit was taken. Probability value $<0.05$ was considered as level of significance.

Results and Observations:

A total 78 number of study subjects 39 patients with GBS as cases and 39 volunteers, were taken as control who were attended in neurology department at BSMMU during the study period, fulfilling the inclusion and exclusion criteria were included in this study.

\section{Table-I}

Distribution of the study subjects by lgG more than 4 fold rise (CMV positive) in the $2^{\text {nd }}$ sample $(n=78)$. Sample - Blood

\begin{tabular}{lccc}
\hline $\begin{array}{l}4 \text { fold rise } \\
\text { of lgG }\end{array}$ & $\begin{array}{c}\text { Case } \\
(\mathrm{n}=39)\end{array}$ & $\begin{array}{c}\text { Control } \\
(\mathrm{n}=39)\end{array}$ & pvalue \\
\hline Positive & $4(10.3)^{\#}$ & $0(0.0)$ & 0.124 \\
Negative & $35(89.7)$ & $39(100.0)$ & \\
\hline Total & $39(100)$ & $39(100)$ & \\
\hline${ }^{*}$ Chi-square test (after Yates correction) was done to \\
measure the level of significance.
\end{tabular}

\#Figure within parentheses indicates in percentage.
4 fold or more rise of IgG titre in $2^{\text {nd }}$ sample considered as CMV positive.

Table I shows the distribution of the study subject by IgG more than 4 fold rise (CMV positive) in the $2^{\text {nd }}$ sample. In the case group $4(10.3 \%)$ cases showed 4 fold rise of IgG and the rest $35(89.7 \%)$ cases showed negative results. In control group 4 fold rise of $\lg G$ was absent in all controls which was $39(100.0 \%)$. The difference between case and control was not statistically significant $(p=0.124)$.

In first case serum anti CMV IgG level in $1^{\text {st }}$ sample was $85.1 \mathrm{AU} / \mathrm{ml}$ and in $2^{\text {nd }}$ sample was $854.1 \mathrm{AU} /$ $\mathrm{ml}$.

In second case serum anti CMV IgG level in $1^{\text {st }}$ sample was $418 \mathrm{AU} / \mathrm{ml}$ and in $2^{\text {nd }}$ sample was 1219 $\mathrm{AU} / \mathrm{ml}$.

In third case serum anti CMV IgG level in $1^{\text {st }}$ sample was $30.7 \mathrm{AU} / \mathrm{ml}$ and in $2^{\text {nd }}$ sample was $270 \mathrm{AU} / \mathrm{ml}$. In forth case serum anti CMV IgG level in $1^{\text {st }}$ sample was $36.1 \mathrm{AU} / \mathrm{ml}$ and in $2^{\text {nd }}$ sample was $320 \mathrm{AU} / \mathrm{ml}$.

\section{Table-II}

Distribution of the study subjects by Anti-CMV $\operatorname{lgM}(n=78)$. Sample-Blood

\begin{tabular}{lccc}
\hline Anti CMV & \multicolumn{2}{c}{ Group } & p value \\
\cline { 2 - 3 } lgM & $\begin{array}{c}\text { Case } \\
(\mathrm{n}=39)\end{array}$ & $\begin{array}{c}\text { Control } \\
(\mathrm{n}=39)\end{array}$ & \\
\hline Positive & $2(5.1)$ & $0(0.0)$ & 0.474 \\
Negative & $37(94.9)$ & $39(100.0)$ & \\
\hline Total & $39(100.0)$ & $39(100.0)$ & \\
\hline
\end{tabular}

${ }^{*}$ Chi-square test (after Yates correction) was done to measure the level of significance.

\#Figure within parentheses indicates in percentage.

Serum anti CMV IgM positive considered as CMV positive.

Table II shows the distribution of the study subjects by anti CMV IgM. In case group anti CMV IgM was positive in $2(5.1 \%)$ cases and the rest 37 (94.9\%) cases were anti CMV IgM negative. In control group anti CMV IgM was negative in all 39 (100.0\%) controls. The difference between case and control was not statistically significant $(p=0.474)$. 
Table-III

Distribution of the Study subjects by CMV detection $(n=78)$

\begin{tabular}{lccc}
\hline CMV & \multicolumn{2}{c}{ Group } & p value \\
\cline { 2 - 3 } detection & $\begin{array}{c}\text { Case } \\
(\mathrm{n}=39)\end{array}$ & $\begin{array}{c}\text { Control } \\
(\mathrm{n}=39)\end{array}$ & \\
\hline Positive & $6(15.4)^{\#}$ & $0(0.0)$ & 0.034 \\
Negative & $33(84.6)$ & $39(100.0)$ & \\
\hline Total & $39(100)$ & $39(100)$ & \\
\hline
\end{tabular}

${ }^{*}$ Chi-square test (after Yates correction) was done to measure the level of significance.

\#Figure within parentheses indicates in percentage.

CMV positive (by $\lg M=02$ and by 4 fold rise of $\lg G$ $=04)=06$.

Table III shows the distribution of the study subjects by CMV detection. In case group CMV was positive in $6(15.4 \%)$ cases and the rest $33(84.6 \%)$ cases were CMV negative. In control group CMV was negative in all $39(100.0 \%)$ controls. The difference between case and control groups was statistically significant $(p=0.034)$.

Table-IV

Distribution of the study subjects by Anti-CMV IgG Sample-1 ( $n=78)$. Sample - Blood

\begin{tabular}{lccc}
\hline Anti-CMV IgG & \multicolumn{2}{c}{ Group } & p value \\
\cline { 2 - 3 } (Sample-1) & $\begin{array}{c}\text { Case } \\
(n=39)\end{array}$ & $\begin{array}{c}\text { Control } \\
(n=39)\end{array}$ & \\
\hline Positive & $33(84.6)$ & $37(94.9)$ & 0.135 \\
Negative & $6(15.4)$ & $2(5.1)$ & \\
\hline Total & $39(100.0)$ & $39(100.0)$ & \\
\hline
\end{tabular}

${ }^{*}$ Chi-square test was done to measure the level of significance.

Figure within parentheses indicates in percentage.

Table IV shows the distribution of the study subjects by Anti-CMV IgG Sample-1. In case group Anti-CMV IgG (Sample-1) was positive in $33(84.6 \%$ ) cases and negative in 6(15.4\%) cases. In control group Anti-CMV IgG (Sample-1) was positive in 37(94.9\%) controls and negative in $2(5.1 \%)$ controls. The difference between case and control was not statistically significant $(p=0.135)$.
Table-V

Distribution of the study subjects by Anti-CMV lgG Sample-2 ( $n=78)$. Sample-Blood

\begin{tabular}{lccc}
\hline $\begin{array}{l}\text { Anti-CMV IgG } \\
\text { (Sample-2) }\end{array}$ & $\begin{array}{c}c \\
\text { Case } \\
(\mathrm{n}=39)\end{array}$ & $\begin{array}{c}\text { Control } \\
(\mathrm{n}=39)\end{array}$ & p value \\
\hline Positive & $35(89.7)$ & $38(97.4)$ & 0.165 \\
Negative & $4(10.3)$ & $1(2.6)$ & \\
\hline Total & $39(100.0)$ & $39(100.0)$ & \\
\hline
\end{tabular}

${ }^{*}$ Chi-square test was done to measure the level of significance.

Figure within parentheses indicates in percentage.

Table $V$ shows the distribution of the study subjects by Anti-CMV IgG Sample-2. In case group Anti-CMV IgG (Sample-2) was positive in $35(89.7 \%$ ) cases and negative in $4(10.3 \%)$ cases. In control group Anti-CMV IgG (Sample-2) was positive in $38(97.4 \%$ ) controls and negative in $1(2.6 \%)$ control. The difference between case and control was not statistically significant $(p=0.165)$. Two sample of blood for serum anti CMV IgG antibody were taken to see the rising titre of $\lg G$.

\section{Table-VI}

Distribution of the study subjects by CMV, IgG $(n=78)$. Sample - Blood

\begin{tabular}{lccc}
\hline $\begin{array}{l}\text { Anti-CMV, } \\
\text { IgG by MEIA }\end{array}$ & $\begin{array}{c}\text { Case } \\
\text { (Mean } \pm \text { SD) }\end{array}$ & $\begin{array}{c}\text { Control } \\
(\text { Mean } \pm \text { SD) }\end{array}$ & \\
\hline $1^{\text {st }}$ Sample & $141.03 \pm 268.80$ & $61.99 \pm 40.51$ & 0.073 \\
$2^{\text {nd }}$ Sample & $195.69 \pm 266.12$ & $61.22 \pm 36.15$ & 0.003 \\
\hline
\end{tabular}

${ }^{*} t$ test was done to measure the level of significance. Figure within parentheses indicates in percentage

Table VI shows the distribution of the study subjects by CMV IgG. In case group the mean value of AntiCMV, IgG by MEIA in $1^{\text {st }}$ sample was $141.03 \pm$ 268.80 and in control group was $61.99 \pm 40.51$. The difference between case and control was not statistically significant $(p=0.073)$. In case group the mean value of Anti-CMV, IgG by MEIA in $2^{\text {nd }}$ sample was $195.69 \pm 266.12$ and in control group was 61.22 \pm 36.15 . The difference between case and control was statistically significant $(p=0.003)$. 


\section{Table-VII}

Distribution of the study subjects by history of respiratory tract infection $(n=78)$ preceding illness (1-4 weeks before)

\begin{tabular}{lccc}
\hline $\begin{array}{l}\text { History of } \\
\text { Respiratory } \\
\text { Tract Infection }\end{array}$ & $\begin{array}{c}\text { Case } \\
(n=39)\end{array}$ & $\begin{array}{c}\text { Control } \\
(n=39)\end{array}$ & p value \\
\hline Present & $18(46.2)$ & $0(0.0)$ & $<0.001$ \\
Absent & $21(53.8)$ & $39(100.0)$ & \\
\hline Total & $39(100.0)$ & $39(100.0)$ & \\
\hline
\end{tabular}

Chi square test (after Yates correction) was done to measure the level of significance.

Odd ratio $(95 \% \mathrm{Cl})=2.86(2.02-4.03)$

Patients with history of respiratory tract infection had 2.86 times more chance to develop GBS than that of control.

Table VII shows the distribution of the study subjects by history of respiratory tract infection. In case group respiratory tract infection was present in 18 (46.2\%) cases; $4(10.2 \%)$ cases were CMV positive and absent in $21(53.8 \%$ ) cases respectively. In control group respiratory tract infection were absent in all $39(100.0 \%)$ controls. The difference between case and control was statistically significant $(p=<0.001)$.

\section{Table-VIII}

Distribution of the study subjects by history of gastroenteritis $(n=78)$

preceding illness (1-4 weeks before)

\begin{tabular}{lccc}
\hline $\begin{array}{l}\text { History of } \\
\begin{array}{l}\text { Gastro- } \\
\text { enteritis }\end{array}\end{array}$ & $\begin{array}{c}\text { Case } \\
(\mathrm{n}=39)\end{array}$ & $\begin{array}{c}\text { Control } \\
(\mathrm{n}=39)\end{array}$ & $\mathrm{p}$ value \\
\hline Present & $11(28.2)$ & $0(0.0)$ & $<0.001$ \\
Absent & $28(71.8)$ & $39(100.0)$ & \\
\hline Total & $39(100.0)$ & $39(100.0)$ & \\
\hline
\end{tabular}

Chi square test (after Yates correction) was done to measure the level of significance.

Odd ratio $(95 \% \mathrm{Cl})=2.39(1.80-3.17)$

Patients with history of gasteroenteritis had 2.39 times more chance to develop GBS than that of control.

Table VIII shows the distribution of the study subjects by history of gastroenteritis. In case group gastroenteritis was present in $11(28.2 \%)$ cases; $2(5.1 \%)$ cases were CMV positive and absent in $28(71.8 \%)$ cases respectively. In control group gastroenteritis was absent in all $39(100.0 \%)$ controls. The difference between case and control was statistically significant $(p=<0.001)$.

Table-IX

Distribution of the study subjects by past history of fever $(n=78)$

preceding illness (1-4 weeks before)

\begin{tabular}{lccc}
\hline History of & \multicolumn{2}{c}{ Group } & p value \\
\cline { 2 - 3 } & $\begin{array}{c}\text { Case } \\
(\mathrm{n}=39)\end{array}$ & $\begin{array}{c}\text { Control } \\
(\mathrm{n}=39)\end{array}$ & \\
\hline Present & $12(30.8)$ & $0(0.0)$ & $<0.001$ \\
Absent & $27(69.2)$ & $39(100.0)$ & \\
\hline Total & $39(100.0)$ & $39(100.0)$ & \\
\hline
\end{tabular}

Chi square test (after Yates correction) was done to measure the level of significance.

Odd ratio $(95 \% \mathrm{Cl})=2.44(1.83-3.27)$

Patients with history of fever had 2.44 times more chance to develop GBS than that of control.

Table IX shows the distribution of the study subjects by history of fever. In case group fever was present in $12(30.8 \%)$ cases and absent in $27(69.2 \%)$ cases 01(2.5\%) cases was CMV positive. In control group fever was absent in all 39(100.0\%) controls. The difference between case and control was statistically significant $(p=<0.001)$.

Table-X

Distribution of the study subject by age $(n=78)$

\begin{tabular}{|c|c|c|c|}
\hline \multirow{2}{*}{$\begin{array}{l}\text { Age in } \\
\text { years }\end{array}$} & \multicolumn{2}{|c|}{ Group } & \multirow[t]{2}{*}{$p$ value } \\
\hline & $\begin{array}{c}\text { Case } \\
(n=39)\end{array}$ & $\begin{array}{l}\text { Control } \\
(n=39)\end{array}$ & \\
\hline$\overline{<20}$ & $8(20.5)$ & $8(20.5)$ & \\
\hline $20-29$ & $13(33.3)$ & $13(33.3)$ & \\
\hline $30-39$ & 5 (12.8) & $5(12.8)$ & \\
\hline $40-49$ & $10(25.6)$ & $10(25.6)$ & \\
\hline $50-59$ & $3(7.7)$ & $3(7.7)$ & \\
\hline Total & $39(100.0)$ & $39(100.0)$ & \\
\hline $\begin{array}{l}\text { Mean } \pm S D \\
\text { (Max-min) }\end{array}$ & $\begin{array}{c}30.82 \pm 12.56 \\
(58-12)\end{array}$ & $\begin{array}{c}31.00 \pm 12.77 \\
(59-12)\end{array}$ & $0.950^{*}$ \\
\hline
\end{tabular}

*t test was done to measure the level of significance. Figure within parentheses indicates in percentage

Table $X$ shows the distribution of the study subjects by age. In both case and control group all were equal in number in the age group of $20-29$ years, $40-49$ years, less than 20 years, $30-39$ years and $50-59$ years which were $13(33.3 \%)$ cases, 
$10(25.6 \%)$ cases, $8(20.5 \%)$ cases, $5(12.8 \%)$ and $3(7.7 \%)$ cases respectively. The mean \pm SD of case and control groups were $30.82 \pm 12.56$ and $31.00 \pm 12.77$ respectively. It was not statistically significant $(p=0.950)$.

Table-XI

Distribution of the study subjects by sex $(n=78)$

\begin{tabular}{lccc}
\hline $\begin{array}{l}\text { Sex } \\
\text { Fever }\end{array}$ & $\begin{array}{c}\text { Case } \\
(\mathrm{n}=39)\end{array}$ & $\begin{array}{c}\text { Control } \\
(\mathrm{n}=39)\end{array}$ & pvalue \\
\hline Male & $25(64.1)$ & $25(64.1)$ & 1.000 \\
Female & $14(35.9)$ & $14(35.9)$ & \\
\hline Total & $39(100.0)$ & $39(100.0)$ & \\
\hline
\end{tabular}

${ }^{*}$ Chi-square test was done to measure the level of significance.

Figure within parentheses indicates in percentage.

Table XI shows the distribution of the study subject by sex. In both case and control groups male and female were equal in number which were $25(64.1 \%)$ and $14(35.9 \%)$ respectively. The difference between case and controls was not statistically significant $(p=1.000)$.

Table-XII

Distribution of the cases by CSF study $(n=39)$

\begin{tabular}{lcc}
\hline CSF Study & Mean \pm SD & Min- Max \\
\hline CSF cell & $1.95 \pm 2.28$ & $0.00-10.00$ \\
CSF sugar & $3.76 \pm 1.35$ & $0.00-7.30$ \\
CSF protein & $78.11 \pm 94.84$ & $0.49-390.00$ \\
\hline
\end{tabular}

Table XII shows the distribution of the cases by CSF study. The Mean \pm SD of CSF cell, CSF sugar and CSF protein were $1.95 \pm 2.28 \mathrm{mg} / \mathrm{dl}, 3.76 \pm 1.35$ cells $/ \mathrm{cmm}$ and $78.11 \pm 94.84 \mathrm{mmol} / \mathrm{L}$ respectively.

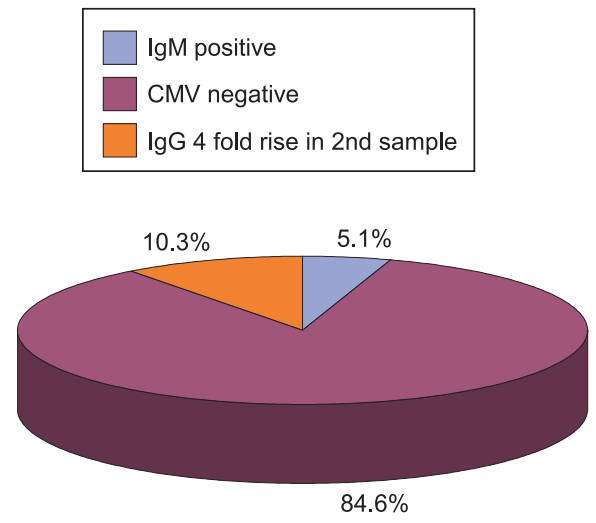

Fig.-1: Distribution of cases by CMV ( $n=39)$
Figure 1: Shows the distribution of cases by CMV. CMV positive cases by IgM positivity (10.3\%), 2 $(5.1 \%)$ by $\lg \mathrm{G} 4$ fold rise in the 2 nd sample positive and rest $33(84.6 \%)$ cases were CMV Negative.

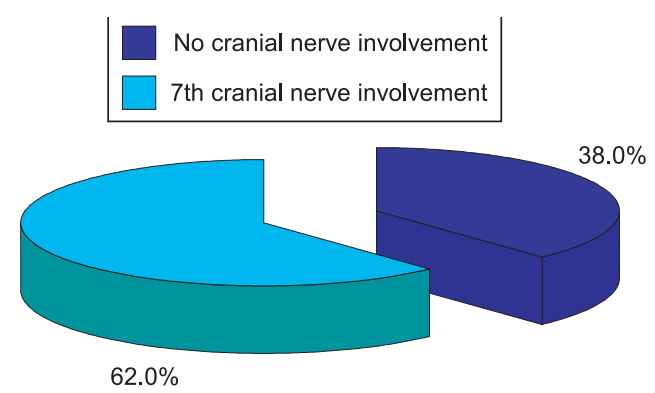

Fig.-2: Distribution of cases by cranial nerves involvement $(n=39)$.

Figure 2: Shows the distribution of cases by cranial nerve involvement. In $24(62.0 \%)$ cases $7^{\text {th }}$ cranial nerve was involved and in $15(38.0 \%)$ cases no cranial nerve was involved.
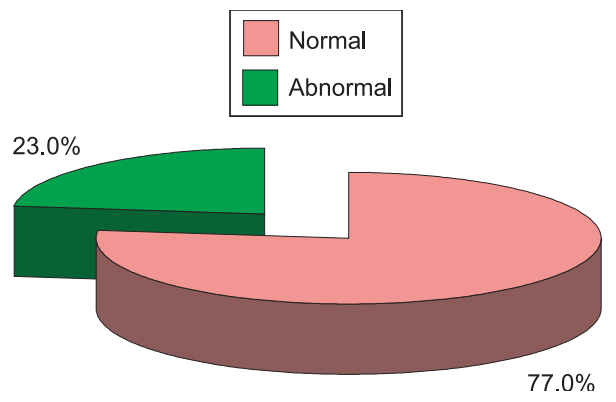

Fig.-3: Distribution of cases by ECG finding $(n=39)$

Fig. 3: depicts that near one-quarter 9 cases $(23 \%)$ had abnormal ECG ( 6 had sinus tachycardia, 3 had sinus bradycardia) and the rest 30 cases $(77 \%)$ had normal ECG.

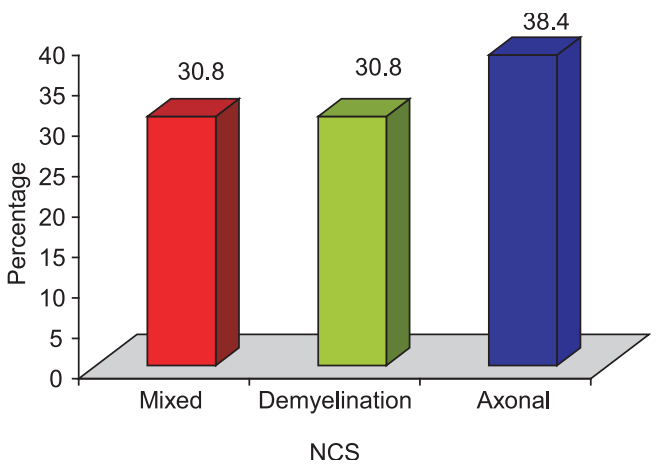

Fig.-4: Distribution of cases by NCS findings $(n=39)$ 
Fig. 4: display the distribution of cases by NCS findings. 12 cases $(30.8 \%)$ shows demyelination and 15 cases $(38.4 \%)$ shows axonal and rest $12(30.8 \%)$ cases shows mixed demyelinating and axonal type of NCS.

\section{Discussion:}

Guillain-Barre' Syndrome (GBS) is the most common cause of acute flaccid paralysis ${ }^{12}$. Annual incidence of GBS is approximately 1-3 cases per 100,000 persons in Europe, US and Australia ${ }^{13}$.

GBS is an autoimmune disorder of the peripheral nervous system (PNS) with a range of presentations from mild to life-threatening paralysis $^{14}$. The etiology of GBS is unknown, yet several studies link some common exposures as precipitating factors, many of which are commonly seen in the primary care setting. Vaccinations, viral infections, and certain type of food poisoning are examples of antecedent factors of $\mathrm{GBS}^{14}$. Due to severity of complications, practitioners need to be aware of what can trigger GBS, who is at risk, how to recognize early signs/ symptoms, what possible prevention exists, and how to educate patients ${ }^{14}$.

Gullian Barre syndrome may occur by primary infection or by reinfection or reactivation of $\mathrm{CMV}^{11}$. The association of cytomegalo virus infection with Guillian-Barre syndrome needs diagnosis of CMV infection which required at least one of the following laboratory method like serology, specific intrathecal antibody production, virus isolation, direct detection of CMV PP65 antigen in blood, CMV culture, Biopsy, positive specific immunohistochemical staining, Polymerase chain Reaction (PCR) assay etc $^{8}$.

A total number of 39 patients with GBS as cases and 39 volunteers, patient's attendants were taken as control who were attended in neurology department at BSMMU during the study period, fulfilling the inclusion and exclusion criteria were included in this study.

The distribution of the study subject by IgGs (Fig.1) more than 4 fold rise in the $2^{\text {nd }}$ sample was recorded in this study. In the case group 4 (10.3\%) cases showed 4 fold rise of $\lg G$ and the rest 35
$(89.7 \%)$ cases showed negative results. In control group 4 fold rise of $\mathrm{IgG}$ was absent in all controls which was $39(100.0 \%)$.

The distribution of the study subjects by Anti-CMV IgM was recorded in this study. Anti-CMV IgM antibody was positive in $2(5.1 \%)$ cases and negative in $37(94.9 \%)$ cases. Anti CMV IgM antibody was negative in all 39(100.0\%) controls. The difference between case and control was not statistically significant $(p=0.474)$. Similar result was reported by Kimoto $\mathrm{K}$ et al. (2006) ${ }^{15}$ and added that CMV infections had a role in the development of GBS. Andary $(2011)^{16}$ reported that CMV could occur after upper respiratory and flu like illness and it was the most common viral trigger of GBS with the presence of Anti-CMV IgM which was consistent with the present study. Jacobs et al., (1996) $)^{17}$ found that in CMV-associated GBS, antibodies were common following CMV infection.

The distribution of the patients by CMV positive was recorded in this study. In case group CMV was overall positive in 6 cases of which lgM was positive in 2 cases and 4 fold rise of $\operatorname{lgG}$ was positive in 4 cases, rest $33(84.6 \%$ ) cases were CMV negative. In control group, CMV was negative in all 39(100\%) cases. That indicated the relationship between CMV and GBS, which was significantly associated. The difference between case and control group was statistically significant $(p=0.034)$. Similar result was reported by Andary MT (2011) $)^{16}$ and added that Cytomegalo virus (CMV) infections were the second most commonly reported infections preceding GBS.

The distribution of the study subjects by Anti-CMV IgG Sample-1 was recorded. In case group AntiCMV IgG (Sample-1) was positive in $33(84.6 \%$ ) cases and negative in $6(15.4 \%)$ cases. In control group Anti-CMV IgG (Sample-1) was positive in $37(94.9 \%)$ controls and negative in $2(5.1 \%)$ controls. The difference between case and control was not statistically significant $(p=0.135)$. The distribution of the study subjects by Anti-CMV IgG Sample-2 was recorded in this study. In case group Anti-CMV IgG (Sample-2) was positive in $35(89.7 \%$ ) cases and negative in $4(10.3 \%)$ cases. In control group Anti-CMV IgG (Sample-2) was positive in $38(97.4 \%)$ controls and negative in $1(2.6 \%)$ control. The 
difference between case and control group was not statistically significant $(p=0.165)$. The distribution of the study subjects by CMV IgG was recorded in this study. In case group the mean value of AntiCMV IgG by MEIA in $1^{\text {st }}$ sample was $141.03 \pm 268.80$ and in control group was $61.99 \pm 40.51$. The difference between case and control group was not statistically significant $(p=0.073)$. In case group the mean value of Anti-CMV, IgG by MEIA in $2^{\text {nd }}$ sample was $195.69 \pm 266.12$ and in control group was 61.22 \pm 36.15 . The difference between case and control group was statistically significant $(p=0.003)$.

The distribution of the study subjects by history of respiratory tract infection was recorded in this study. In case group respiratory tract infection was present in $18(46.2 \%)$ cases; $4(10.2 \%)$ cases were CMV positive and absent in $21(53.8 \%)$ cases. In control group respiratory tract infection were absent in all $100.0 \%$ cases. The difference between case and control group was statistically significant $(p=<0.001)$. The distribution of the study subjects by history of gasteroenteritis was recorded in this study. In case group the Gastroenteritis was present in $11(28.2 \%)$ cases; $2(5.1 \%)$ cases was CMV positive and negative in $28(71.8 \%$ ) cases. In control group gastroenteritis was absent in all 39(100.0\%) controls. The difference between case and control group was statistically significant $(p=<0.001)$. The distribution of the study subjects by past history of fever was recorded in this study. In case group fever was present in $12(30.8 \%)$ cases; $1(2.5 \%)$ case was CMV positive and negative in $27(69.2 \%)$ cases. In control group fever was absent in all 39(100.0\%) controls. The difference between case and control group was statistically significant $(p=<0.001)$. Similar result was reported by Andary MT $(2011)^{16}$ and mentioned that GBS was considered to be a postinfectious, immune-mediated disease targeting peripheral nerves. Baravelli M et al., (2009) ${ }^{18}$ added that up to two thirds of patients report an antecedent bacterial or viral illness prior to the onset of neurologic symptoms. Similarly Nelson $L$ et al., $(2009)^{19}$ also reported that respiratory tract infections were most frequently reported, followed by gastrointestinal infections which was consistent with the present study. In another similar study it was mentioned that other systemic illnesses which was manifested by fever have also been associated with $\mathrm{GBS}^{16}$.

The distribution of the study subjects by age was recorded in this study. In both case and control groups all were equal in number in the age group of 20-29 years, $40-49$ years, less than 20 years, 30 -39 years and $50-59$ years which were $13(33.3 \%)$ cases, $10(25.6 \%)$ cases, $8(20.5 \%)$ cases, 5 $(12.8 \%)$ and $3(7.7 \%)$ cases respectively. The mean \pm SD of case and control groups were $30.82 \pm 12.56$ and $31.00 \pm 12.77$ respectively which was not statistically significant $(p=0.950)$. Similar result was reported by Jiang $\mathrm{GX}^{20}$ and mentioned that GBS had been detected in all age groups, with the syndrome occurring at any time between infancy and old age. In the United States, the syndrome's age distribution seemed to be bimodal, with a first peak in young adulthood (age 15-35 years) and a second, higher one in elderly persons (age 50-59 years). Infants appeared to have the lowest risk of developing $\mathrm{GBS}^{20}$.

The distribution of the study subjects by sex was recorded in this study. In both case and control groups male and female was equal in number which were $25(64.1 \%)$ and $14(35.9 \%)$ respectively which was not statistically significant $(p=1.000)$. Similar result was reported by Andary MT $(2011)^{16}$ and mentioned that GBS had a male-to-female ratio of $1.5: 1$; male preponderance was seen especially in older patients. However, a Swedish epidemiologic study reported that GBS rates decrease during pregnancy and increase in the months immediately following delivery ${ }^{21}$.

The distribution of the cases by ECG (Fig.-3) was recorded in this study. Near the one-quarter cases $9(23 \%)$ has abnormal ECG (6 had sinus tachycardia, 3 had sinus bradycardia) and the rest $30(77 \%)$ cases had normal ECG. Distribution of cases by cranial nerve involvement which shows (Fig.-2). 15 (38\%) had no cranial nerve involvement and $24(62.0 \%)$ had $7^{\text {th }}$ cranial nerve involvement. Distribution of cases by NCS (Fig.-4) in this study shows 12 (30.8\%) were demyelinating, 15(38.4\%) were axonal and rest $12(30.8 \%)$ cases were mixed type. The distribution of cases by CSF study shows the mean \pm SD of CSF cell, CSF sugar and CSF 
protein were $1.95 \pm 2.28$ cells $/ \mathrm{cmm}, 3.76 \pm 1.35$ $\mathrm{mg} / \mathrm{dl}$ and $78.11 \pm 94.84$ respectively.

However, although numerous studies had lead to an accurate description of the GBS related to C. jejuni (Cj-GBS), the GBS associated with primary CMV infection (CMV-GBS) remained poorly documented ${ }^{22}$. Current data were available from just a few studies, most of which had included only a small number of CMV-GBS cases ${ }^{11}$. In these studies, recent primary CMV infection was clearly deûned and the presence or absence of CMV DNA in the blood was not documented ${ }^{22}$. Because of the small number of patients studied, epidemiological characteristics and speciûc prognostic features were not speciûed, and the risk of developing GBS following primary CMV infection was not determined. Visser et al., (1996) ${ }^{7}$ in another study had mentioned that cytomegalovirus (CMV) infection accounts for the most common viral triggers of GBS.

This present study strongly showed that GuillainBarré syndrome (GBS) had great association with cytomegalovirus (CMV) infection.

\section{References:}

1. Burns TM. Guillain-Barre' Syndrome. Semin Neurol ; 2008; 28(2):152-167.

2. Prevots DR, Sutter RW. Assessment of Guillain-Barre syndrome mortality and morbidity in the United States: implications for acute flaccid paralysis surveillance. J Infect Dis; 1997; 175 Suppl 1:S151-155.

3. Fletcher DD, Lawn ND, Wolter TD. Long-term outcome in patients with Guillain-Barré syndrome requiring mechanical ventilation. Neurology; 2000; 54(12): 23112315.

4. Jacobs BC, van Doorn PA, Ruts L. Clinical features, pathogenesis, and treatment of Guillain-Barre syndrome. Lancet Neurol; 2008; 7: 939-950.

5. Ilyas AA, Mithen FA, Chen Z-W. Search for antibodies to neutral glycolipids in sera of patients with Guillain-Barré syndrome. J Neurol Sci; 1991; 102: 67-75.
6. Koga M, Takahashi M, Masuda M. Campylobacter gene polymorphism as a determinant of clinical features of Guillain-Barre syndrome. Neurology; 2005; 65(9): 1376-1381.

7. Visser LH, van der Meché FG, Meulstee J, Rothbarth PP, Jacobs BC, Schmitz PI et al. Cytomegalovirus infection and Guillain-Barré syndrome: the clinical, electrophysiologic, and prognostic features. Dutch Guillain-Barré Study Group. Neurology; 1996; 47(3): 668-673.

8. Rafalidis PI, Mourtzookou EG, Varbobitis IC and Falagas ME. Severe cytomegalo virus infection in apparently immunocompetent patient: a systemic review; Virology Journal; 2008; 5: 47.

9. Irie S, Saito T, Nakamura K. Association of anti-GM2 antibodies in Guillain-Barré syndrome with acute cytomegalo virus infection. J Neuroimmunol; 1996; 68:19-26.

10. Khalili-Shirazi A, Gregson N, Gray I, Rees J, Winer J, Hughes R. Antiganglioside antibodies in Guillain-Barré syndrome after a recent cytomegalo virus infection. J Neurol Neurosurg Psychiatry; 1999; 66: 376-379.

11. Steininger C, Seiser A, Gueler N, Stöckl EP, Stephan W, Aberle, Primary cytomegalo virus infection in patient with Guillan Barre syndrome. Journal of neuro Immunology; 2007; 183: 214-219.

12. Nachamkin I, Allos BM, \& Ho T. 1998. Campylobacter Species and Guillain-Barre' Syndrome. Clinical Microbiology Reviews, 11, 3. http://www.ncbi.nlm.nih. gov/entrez

13. Seneviratne, U. Guillain-Barre' syndrome. Institute of Neurology, April, 2000. http:// www.ncbi.nlm.nih.gov

14. McClellan K, Armeau E, Parish T. Recognizing Guillain-Barré Syndrome in the Primary Care Setting. The Internet Journal of Allied Health Sciences and Practice; 2007; 5(1):1-8.

15. Kimoto K, Koga M, Odaka M, Hirata K, Takahashi M, Li J, et al. Relationship of bacterial strains to clinical syndromes of Campylobacter-associated neuropathies. Neurology; 2006; 67(10):1837-1843. 
16. Andary MT. 2011. Guillain-Barre Syndrome. Updated: Aug 26, 2011. http:// emedicine.medscape.com/article/315632overview\#a0101

17. Jacobs BC, van Doorn PA, Schmitz PI. Campylobacter jejuni infections and anti-GM1 antibodies in Guillain-Barré syndrome. Ann Neurol; 1996; 40(2):181-187.

18. Baravelli M, Fantoni C, Rossi A. Guillain-Barré syndrome as a neurological complication of infective endocarditis. Is it really so rare and how often do we recognise it?. Int J Cardiol; 2009; 133 (1): 104-105.

19. Nelson L, Gormley R, Riddle MS, Tribble DR, Porter CK. 2009. The epidemiology of Guillain-
Barré Syndrome in U.S. military personnel: a case-control study. BMC Res Notes; 2:171.

20. Jiang GX, de Pedro-Cuesta J, Strigård K, Olsson T, Link H. Pregnancy and GuillainBarré syndrome: a nationwide register cohort study. Neuroepidemiology; 1996; 15(4):192200.

21. Evans OB, Vedanarayanan V. Guillain-Barré syndrome. Pediatr Rev. 1997;18(1):10-16.

22. Orlikowski D, Porcher R, Sivadon-Tardy V, Quincampoix JC, Raphae JC, Durand MC, et al. Guillain-Barre Syndrome following Primary Cytomegalovirus Infection: A Prospective Cohort Study. Clinical Infectious Diseases; 2011; 52(7):837-844. 